\title{
The Common Law Basis of Automobile Guest Statutes
}

Approximately half the states have automobile guest statutes, ${ }^{1}$ which typically provide that an automobile guest cannot recover damages against a host driver for injuries caused by the host's ordinary negligence. A host driver is liable only if his conduct involves "gross negligence," "recklessness," "willful misconduct," intoxication, or some equivalent. ${ }^{2}$ The statutes thus provide that the duty of care a host driver owes to guest passengers is less than the ordinary duty of care owed to paying passengers or strangers (other drivers, their passengers, pedestrians).

Guest statutes have frequently been challenged as violating the equal protection clause of the fourteenth amendment. ${ }^{3}$ The consti-

1 A list of all such statutes, including those which have been repealed, may be found in Comment, The Constitutionality of Automobile Guest Statutes: A Roadmap to the Recent Equal Protection Challenges, 1975 BRIGHAM Young U.L. REv. 99 n.1 (1975) [hereinafter cited as Roadmap Comment]. The statute of Alabama is illustrative:

The owner, operator or person responsible for the operation of a motor vehicle shall not be liable for loss or damage arising from injuries to or death of a guest while being transported without payment therefor in or upon said motor vehicle, resulting from the operation thereof, unless such injuries or death are caused by the willful or wanton misconduct of such operator, owner or person responsible for the operation of said motor vehicle.

Ala. Code tit. 36, § 95 (1959).

2 See, e.g., Neb. Rev. Stat. § 39-6,191 (1974) ("gross negligence" or intoxication).

3 Since their inception the guest statutes have been unpopular with courts and commentators. See, e.g., W. Prosser, LaW of Torts 186-87 (4th ed. 1971) and authorities cited therein. Much of the considerable body of judicial interpretation of the statutes has been concerned to limit their operation: thus the definition of an automobile "guest" may be given a narrow construction while the notion of what constitutes "recklessness," for instance, is broadened. An overview of these constructional problems may be found at $2 \mathrm{~F}$. HaRPER \& F. JAMES, LAW of ToRTs 950-62 (1956). See generally Annot., 39 A.L.R.3d 1083 (1971); Annot., 39 A.L.R.3d 1177 (1971); Annot., 39 A.L.R.3d 1224 (1971). These annotations discuss the circumstances which may take a passenger out of the "guest" category. See also Annot., 6 A.L.R.3d 769 (1966); Annot., 6 A.L.R.3d 832 (1966); Annot., 96 A.L.R. 1479 (1935); Annot., 86 A.L.R. 1145 (1933); Annot., 74 A.L.R. 1198 (1931). These annotations discuss the circumstances affording an inference of "aggravated misconduct" on the part of the driver. For a discussion of the constitutionality of automobile guest statutes, see Annot., 66 A.L.R.3d 532 (1975).

Courts in jurisdictions without guest statutes have found reasons to refuse to apply the statutes in choice-of-law situations. See Clark v. Clark, 107 N.H. 351, 356-57, 222 A.2d 205, 210 (1966); Babcock v. Johnson, 12 N.Y.2d 473, 191 N.E.2d 279, 240 N.Y.S.2d 743 (1963). See generally Ehrenzweig, Guest Statutes in the Conflict of Laws, 69 YaLE L.J. 595 (1970). 
tutional attack has come in two distinct waves. In the first set of challenges, arising soon after the first statutes were enacted, acts with typical ${ }^{4}$ provisions were uniformly upheld. The leading case of the series was Silver $v$. Silver ${ }^{5}$ in which the Supreme Court upheld the Connecticut guest statute, ${ }^{6}$ the first to be enacted. Silver $v$. Silver remains the only Supreme Court decision on the constitutionality of guest statutes. The second wave of the constitutional attack began with the recent decision of the California Supreme Court in Brown v. Merlo, ${ }^{7}$ which invalidated that state's guest statute for failure to meet equal protection standards. As of this date, the courts of seven states have followed Brown v. Merlo in nullifying their guest statutes; another ten courts have expressly declined to do so. ${ }^{8}$

Legislative repeal has been far less common. Guest statutes have been repealed in Connecticut (1937), Vermont (1970), Florida (1972), Washington (1974), Montana (1975) and Colorado (1975). Recent amendments to the guest statutes of Illinois, Texas, and Virginia have limited or nullified their effect. See Roadmap Comment, supra note 1, at 99 n.1.

- The guest statutes originally enacted by Oregon and Delaware were atypical in providing that a guest passenger should have no right of action against his host for any degree of negligence; in other words, no duty of care was imposed on the host driver. Both statutes were found to violate state constitutional guarantees preserving for citizens a right of action for personal injuries. Coleman v. Rhodes, 35 Del. 120, 159 A. 649 (1932); Stewart v. Houk, 127 Ore. 589, 271 P. 998 (1928). The statutes were later amended to allow an action alleging aggravated misconduct on the part of the driver, and, as amended, they were upheld by the courts. Gallegher v. Davis, 37 Del. 380, 183 A. 620 (1936); Perozzi v. Ganiere, 149 Ore. 330, 40 P.2d 1009 (1935).

5280 U.S. 117 (1929).

- Ch. 308, §§ 1-2, [1927] Conn. Acts 4404 (repealed 1937).

78 Cal. 3d 855, 506 P.2d 212, 106 Cal. Rptr. 388 (1973). For discussion of the case, see McAdams, Automobile Guest Statutes-A Constitutional Analysis, 41 INs. Counsel J. 408 (1974); Note, Guest Statutes: Have Recent Cases Brought Them to the End of the Road? 49 Notre Dame Law. 447 (1973); 23 Drake L. Rev. 216 (1973). A summary of the case law subsequent to Brown is provided by Note, Guest Statutes and the Common Law Categories: An Inseparable Duality? 51 Notre Dame LAw. 467, 473-80 (1976).

"State court decisions following Brown v. Merlo are: Thompson v. Hagan, 96 Idaho 19, 523 P.2d 1365 (1974); Henry v. Bauder, 213 Kan. 751, 518 P.2d 362 (1974); Manistee Bank \& Trust Co. v. McGowan, 394 Mich. 655, 232 N.W.2d 636 (1975); Laakonen v. Eighth Judicial Dist. Court, 91 Nev. 506, 538 P.2d 574 (1975); McGeehan v. Bunch, 88 N.M. 308, 540 P.2d 238 (1975) (prospective application); Johnson v. Hassett, 217 N.W.2d 771 (N.D. 1974). In Primes v. Taylor, 43 Ohio St. 2d 195, 331 N.E.2d 723 (1975), the court found that Brown v. Merlo lacked "persuasive force," but nevertheless found Ohio's guest statute unconstitutional through similar reasoning.

Cases upholding guest statutes after reconsideration in light of Brown v. Merlo are: Beaseley v. Bozeman, 294 Ala. 288, 315 So. 2d 570 (1975); Justice v. Gatchell, 325 A.2d 97 (Del. 1974); Keasling v. Thompson, 217 N.W.2d 687 (Iowa 1974); Botsch v. Reisdorff, 193 Neb. 165, 226 N.W.2d 121 (1975); Duerst v. Limbocker, 269 Ore. 252, 525 P.2d 99 (1974); Behrns v. Burke, 229 N.W.2d 86 (S.D. 1975); Tisko v. Harrison, 500 S.W.2d 565 (Tex. Civ. App. 1973); Cannon v. Oviatt, 520 P.2d 883 (Utah 1974), appeal dismissed, 419 U.S. 810 (1974). The courts of two additional states have taken note of the Brown v. Merlo decision but have upheld their guest statutes, relying on prior decisions rather than reexamining the 
The equal protection challenge to guest statutes has focused on whether the classifications arguably created by the statutes ${ }^{9}$ are rationally related ${ }^{10}$ to achieving the legislature's legitimate objectives in passing such laws. In Brown and the other recent cases, courts have generally assumed that guest statutes were enacted to promote hospitality and to prevent collusive lawsuits and have tested the constitutionality of guest statute classifications by examining their relationship to achieving these goals. ${ }^{11}$

But the commonly accepted version of the purposes of guest statutes $^{12}$ is purely speculative. ${ }^{13}$ This comment argues that the "purpose" of guest statutes cannot be discerned without reference to their common law origins, a source of understanding which has been overlooked in recent commentary and court decisions. Guest statutes were based on the common law doctrine of degrees of care as it had developed over two centuries. This comment traces the

constitutional question. White v. Hughes, 257 Ark. 627, 519 S.W.2d 70 (1975); Richardson v. Hansen, 186 Colo. 346, 527 P.2d 536 (1974).

In Sidle v. Majors, 536 F.2d 1156 (7th Cir. 1976), a diversity action, the court of appeals-despite its express approval of the logic of Brown v. Merlo-upheld the Indiana guest statute, on the grounds that the Supreme Court dismissal of the appeal in Cannon v. Oviatt, supra, constituted an adjudication on the merits.

- See text and notes at notes 69-80 infra.

10 The rational relationship test is one tier of the traditional two-tier approach to equal protection analysis. Under this test a legislative classification must be rationally related to a legitimate state purpose to withstand constitutional attack. Legislative classifications which either affect a "suspect class" (such as race) or affect a "fundamental interest" (an interest involved which is either explicitly or implicitly guaranteed by the Constitution) are tested under the more rigorous "strict scrutiny" standard, requiring the state to show a compelling government interest to justify the classification. For a recent affirmation of the two-tier approach, see San Antonio v. Rodriguez, 411 U.S. I (1973). Guest statutes are a form of economic and social legislation, an area which has traditionally been subjected to minimum scrutiny under the rational relationship test. See, e.g., Dandridge v. Williams, 397 U.S. 471 (1970). No court which has considered the constitutionality of guest statutes has suggested that the strict scrutiny standard is applicable. But some commentators have interpreted Brown as representing a third "tier," between strict scrutiny and rational relationship. See, e.g., Roadmap Comment, supra note 1, at 111-23.

$"$ Compare Brown v. Merlo, 8 Cal. 3d 855, 506 P.2d 212, 106 Cal. Rptr. 388 (1973) (no rational relationship perceived to exist), with Tisko v. Harrison, 500 S.W.2d 565 (Tex. Civ. App. 1973) (rejecting Brown and holding that a rational relationship does exist). For a detailed discussion of equal protection analysis as applied to guest statutes, see Roadmap Comment, supra note 1.

12 These rationales for the passage of guest statutes have been discussed by several commentators. See, e.g., Roadmap Comment, supra note 1, at 103-04. Frequently alleged as motivating factors behind these reasons are the economic conditions of the Depression, the need to protect a large number of uninsured drivers, particularly from being victimized by suits by hitchikers, and effective lobbying by insurance companies.

13 The absence of informative legislative history for guest statutes has been noted by commentators. See, e.g., Note, The Present Status of Automobile Guest Statutes, 59 CoRnel L. REv. 659 (1974). 
history of that doctrine in order to demonstrate that the basis and rationale of guest statutes rests in conscious legislative decisions to adopt the common law rule which distinguished on the grounds of natural justice between the duties of care owed by a host driver who is compensated and one who is not. Finally, this comment argues that once their legal basis is understood, guest statutes should withstand constitutional attack.

\section{The Common Law Origins of Guest Statutes}

The general principle underlying guest statutes-that the legal duty owed by one person to another varies with the circumstances of their relationship-is a basic theme in the development of tort law and is especially significant near the boundary between tort and contract. The law of torts can be viewed as establishing a set of obligations of persons toward each other-a standard of behavior, a uniform duty of care which is owed and may be demanded ${ }^{14}$-but the duties thus generally imposed govern the relations of persons who meet each other as strangers, without the benefit of a prior consensual arrangement to order their relations. If the tort law is seen as an implied, standard-form "social contract" by which each of us agrees to employ "ordinary care" in our behavior toward strangers in exchange for the right to demand an equivalent level of care in return, it must be kept in mind that the terms of that contract are subject to variation or nullification by private ordering between the parties.

Persons may choose to fix their respective duties and liabilities by express contract. ${ }^{15}$ But even in the absence of an express agreement, the duty of care which would obtain between strangers may be modified by circumstances placing the parties on a different footing from that of persons between whom there exists no private arrangement of duties. Some form of agreement, implicit in the acts of the parties if not expressed in words, removes them from the

is When men live in society, a certain average of conduct, a sacrifice of individual peculiarities going beyond a certain point, is necessary to the general welfare. If, for instance, a man is born hasty and awkward, is always having accidents and hurting himself or his neighbors, no doubt his congenital defects will be allowed for in the courts of Heaven, but his slips are no less troublesome to his neighbors than if they sprang from guilty neglect. His neighbors accordingly require him, at his proper peril, to come up to their standard, and the courts which they establish decline to take his personal equation into account.

O.W. Holmes, The Common Law 86-87 (Howe ed. 1963).

${ }_{15}$ The most common ways of doing so, in the area of tort liability, would be by means of express warranty, disclaimer, or waiver. 
category of strangers; they become persons who have chosen to stand vis-a-vis each other in a particular way. Their relations are governed by a private treaty, implied in fact, which supersedes the "social contract" under which a uniform duty of care would otherwise be owed. ${ }^{16}$

Automobile guest statutes cover one of the various situations in tort law where the circumstances of the parties' relationships result in such contractlike modifications of the "ordinary" duty of care. ${ }^{17}$ The purposes of the courts and legislatures in adopting the varying

18 The distinction in the law of torts between obligations to "strangers" and to persons who are not, in a legal sense, "strangers" is not often articulated in these terms, although it is implicit in a wide variety of tort situations. The circumstances which will remove a party from the category of "stranger," while not making him a party to a contract, can best be described as contractlike in nature and effect. While there is a threshold reluctance to admit the language of contracts to a discussion of tort principles, in the present context it seems more useful to consider, in place of arbitrary classifications of subject matter, a "generalized theory of civil obligation." See generally G. Gilmore, The Death of Contract 87-94 (1974).

A recent discussion of another traditional tort subject, medical malpractice, emphasizes the distinction between duties owed to strangers and to those with whom one stands in a consensual arrangement.

The two major sources of obligation in our private law are tort and contract, and the law of medical malpractice illustrates the importance of understanding their interaction and of setting the proper boundary line between them. Where the two parties to a particular suit stand as strangers to each other before the harm has occurred, the tort solution is the only possible one, there being in the nature of the situation no contractual alternative. Yet where the parties have entered into a consensual relationship, the problem assumes in the end a contractual dimension even if the subject matter of the particular case is the physical harm to the plaintiff.

Epstein, Medical Malpractice: The Case for Contract, 1976 A.B.F. Research J. 87, 94; cf. Posner, The Rights of Creditors of Affiliated Corporations, 43 U. CHI. L. REv. 499, 506-07, 519-20 (1976).

17 The varying duties owed at common law by a landowner to trespassers, licensees, and invitees embody modified standards of care contingent on circumstances rather than express agreement. See W. Prosser, LaW of ToRTs 398-99 (4th ed. 1971); Harper, Laube v. Stevenson: A Discussion, 25 Conn. B.J. 123, 132 (1951); James, Tort Liability of Occupiers of Land: Duties Owed to Licencees and Invitees, 63 YALE L.J. 605 (1954). The doctrine of assumption of risk is also readily understandable as a contractlike variation of the standard of care. The action of the plaintiff (in knowingly assuming a risk) takes the place of a written waiver, and the law will infer an agreement by the plaintiff to forgo a tort remedy which might otherwise be available. W. PROSSER, LAW of ToRTS 439 (4th ed. 1971). Conversely, a preexisting relation between the parties-arising from their actions or status-may impose a higher duty of care than that owed between strangers. A clear example is liability for negligent misrepresentation. The traditional view is that while there is no liability for honest, gratuitous, negligent misrepresentation between strangers, an action will lie where the parties stand in a relationship giving rise to an extraordinary duty. Such a relationship can be fiduciary, contractual (express or implied), or some other "special relationship." The cornerstone of the decisions denying any action for merely negligent misrepresentation is Derry v. Peek, 14 App. Cas. 337 (1889). Although the modern tendency is to recognize "special relationships" in an increasingly broad range of circumstances, there is still no liability for negligent misrepresentation where no circumstantial grounds for duty are present. See Hadley Byrne \& Co. v. Heller \& Partners, [1964] A.C. 465. 
degrees of care approach in the automobile guest situation can best be understood by tracing the historical development of that approach from its early application in the law of bailments.

\section{A. The Common Law of Bailments and the Origin of the Doctrine of Varying Duties of Care}

The common law recognized varying duties of care first in the context of bailments, ${ }^{18}$ and the early cases discussing gratuitous bailments ${ }^{19}$ illuminate the rationale for holding that a gratuitous undertaking imposes a lower degree of care than an undertaking that is compensated. Since Lord Holt's opinion in the landmark case of Coggs $v$. Bernard, ${ }^{20}$ the law of torts has recognized that a bailee who benefits from a bailment will be held to a higher standard of care than one who does not. Lord Holt's analysis consists of a sixfold classification of bailments drawn indirectly from Roman law. ${ }^{21}$ The various types of bailments are distinguished according to

18 "Without professing to enter into a minute criticism, it may be said that a bailment is a delivery of a thing in trust for some special object or purpose, and upon a contract, express or implied, to conform to the object or purpose of the trust." J. STORY, COMMENTARIES ON THE LAW OF BAILMENTS § 2, at 5 (9th ed. 1878) [hereinafter cited as STORY ON BaILMENTS]. Justice Story's definition of a bailment gives little indication of the range of commercial transactions which were considered to be governed by the law of bailments in the nineteenth century. Story's treatise, first published in 1832 and continued through nine editions extending over fifty years, represents the high-water mark of learning on "bailments." By the end of the century, much of the traditional subject matter of bailments had been absorbed into the newly discovered law of contract.

" Gratuitous bailments are of particular interest because they are less likely to have been the subjects of express contracts between the parties and because the common law was prepared to invest with legal validity and to discriminate among a variety of gratuitous transactions. The preoccupation with consideration which characterized the common law of contracts made it a far less versatile instrument for making such distinctions.

202 Ld. Raym. 909, 92 Eng. Rep. 107 (K.B. 1703). The defendant, Bernard, had undertaken wholly gratuitously to transport hogsheads of brandy belonging to Coggs. Due to Bernard's negligence, one of the casks broke and some of the brandy was lost. The question was whether Bernard was liable to Coggs for his negligence under the circumstances of the bailment.

${ }^{21}$ Lord Holt attempted to disguise somewhat the civil law origins of his analysis of bailments by repeated citations to Bracton, "which is a full authority, if it be not thought too old." Id. at 919, 92 Eng. Rep. at 113. The discussion of bailments in Bracton's De Legibus et Consuetudinis Angliae is for the most part a paraphrase of Justinian's Institutes.

The first, second, and sixth categories of the scheme have particular relevance to the problem of gratuitous undertakings. The classification scheme is briefly as follows. (The quotations are from Lord Holt's opinion and may be found at 2 Ld. Raym. 909, 912-19, 92 Eng. Rep. 107, 109-13).

(1) The "bare naked bailment of goods, delivered by one man to another to keep for the use of the bailor" (Roman depositum). The simple gratuitous bailee "is not answerable, if they are stole without any fault in him, neither will a common neglect make him chargeable, but he must be guilty of some gross neglect." The bailee is not required to exert himself to any more than his accustomed standard of care. "As suppose the bailee is an idle, careless, 
the circumstances of the transaction, with the extent of the bailee's obligation turning on the nature of the relationship between the bailor and bailee. The determining factor in each case is the balance of the benefit conferred in a given situation. The bailee who himself benefits from a bailment will be held to a higher standard of care than he who undertakes the safekeeping of his friend's goods with no benefit to himself whatsoever. The rationale behind these distinctions is recognizable as a simple kind of distributive justice. Without Lord Holt's intervention, however, this flexible resolution of the duty question was hardly an inevitable one..$^{22}$

The full extent to which Lord Holt's opinion represented a new approach may be demonstrated by reference to the law of bailments prior to Coggs $v$. Bernard. For the century preceding Coggs, the leading authority on bailments was Southcote's Case ${ }^{23}$ which held

drunken fellow, and comes home drunk, and leaves all his doors open, and by reason thereof the goods happen to be stolen with his own; yet he shall not be charged, because it is the bailor's own folly to trust such an idle fellow. So that this sort of bailee is the least responsible for neglects, and under the least obligation of any one, being bound to no other care of the bailed goods, than he takes of his own." The emphasis on the bailor's freedom of choice-in modern paraphrase, his opportunities for cost avoidance-is a central element in the rationale of modified liability for gratuitous transactions.

(2) "The second sort is, when goods or chattels that are useful, are lent to a friend gratis, to be used by him . . ." (Roman commodatum). The bailee's duty is "the strictest care and diligence, to keep the goods, so as to restore them back again to the lender, because the bailee has a benefit by the use of them, so as if the bailee be guilty of the least neglect, he will be answerable. ..."

(3) "The third sort is, when goods are left with the bailee to be used by him for hire ..." (Roman locatio et conductio).

(4) "The fourth sort is, when goods or chattels are delivered to another as a pawn, to be a security to him for money borrowed of him by the bailor. . ." (Roman vadium).

(5) "The fifth sort is when goods or chattels are delivered to be carried, or something is to be done about them for a reward to be paid by the person who delivers them to the bailee, who is to do the thing about them." A private carrier for hire is held to the highest standard of diligence; a common carrier is held strictly liable. Holmes argued that the special liability of common carriers had no Roman antecedent and was purely a common law development. O.W. Holmes, The Common Law 143-59 (Howe ed. 1963).

(6) "The sixth sort is when there is a delivery of goods or chattels to somebody, who is to carry them, or do something about them gratis, without any reward for such his work or carriage . . ." (Roman mandatum, Anglicized to mandate). The precise degree of diligence to which the mandatary should be held is unclear, as neither Lord Holt nor any Roman authority is explicit on the point. Sir William Jones states as the general rule that the mandatary is "considered as having engaged himself to use a degree of diligence and attention adequate to the performance of his undertaking." W. JONES, ESSAY ON THE LAW OF BAILMENTS 53-54 (1781) [hereinafter cited as JoNES ON BAILMENTS]. Others have argued that the mandatary, like the purely gratuitous bailee, is obliged to use only slight care. For a variety of views on the subject, see STORY ON Bailments, supra note 18 , $\S \S 174-88$, at 168-81.

22 The statement of facts in Lord Raymond's report shows that the parties in Coggs $v$. Bernard argued the case on the absolutist common law grounds of duty of care vel non. See 2 Ld. Raym. 909, 92 Eng. Rep. 107 (K.B. 1703).

4 Coke 836, 76 Eng. Rep. 1061 (K.B. 1601). 
that a gratuitous bailee was strictly liable for the safe return of the goods. ${ }^{24}$ The fact that the transaction was gratuitous in no way affected the duty imposed. A gratuitous bailee (like any other bailee) could limit his liability by express stipulation, but in the absence of express private ordering, Southcote's Case stood for the proposition that where a duty was imposed at all, it was a duty of one strict and inflexible standard of care. In place of this all or nothing obligation, which had come to be perceived as intolerably harsh, ${ }^{25}$ Coggs substituted a flexible system of differing duties, taking account of circumstances which seemed to affect the natural justice of a given situation as between the parties. Henceforth, a common carrier might be held strictly liable; a paid bailee or one who had the use of bailed goods might owe a duty of reasonable and prudent care; a gratuitous bailee might owe a duty of slight care, that is, only the duty to exercise the same care he devoted to his own possessions.

This flexible scheme of obligations is in keeping with that tendency of the general tort law which allows the circumstantial relations of the parties to modify the obligations which would be fixed between them if they stood towards each other as entire strangers. The underlying rationale of the common law recognition of varying degrees of care in the context of gratuitous bailments-insofar as "rationale" is taken to mean the purpose, the intention, the reason why-is, precisely, the choice of Coggs $v$. Bernard over Southcote's Case as a means of resolving the parallel questions presented. This choice is no arbitrary formulation. It embodies a conscious and rational preference for a scheme of civil obligations which tends to be flexible rather than absolute.

\section{B. The Development of the Doctrine of Varying Duties of Care}

To trace the common law ancestry of the automobile guest

2: Southcote had delivered certain goods to Bennet for gratuitous safekeeping, and one J.S. had stolen them feloniously out of Bennet's possession. The question for the court was whether Bennet was liable for the goods. There was no allegation that Bennet had been negligent, and it appears to have been assumed that Bennet had taken the same care of Southcote's goods as he was accustomed to take of his own. The court gave judgment for the plaintiff, "because the plaintiff delivered the goods to be safe kept, and the defendant had took it upon him by the acceptance upon such delivery, and therefore he ought to keep them at his peril, although in such case he should have nothing for his safe keeping." Id., 76 Eng. Rep. at 1061-62.

${ }_{25}$ See Coggs v. Bernard, 2 Ld. Raym. 909, 909-10, 92 Eng. Rep. 107, 107-08 (1703). Several of the justices in Coggs, moreover, expressed their doubts that Lord Coke's formulation of the law in Southcote's Case had ever been correct, but this view has been challenged. O.W. Holmes, The Common Law 142 (Howe ed. 1963). 
statutes it is sufficient to show the continuity of the common law learning on gratuitous bailments, through its transformation into the more generalized doctrine of degrees of care, to the point where that doctrine was adopted by the "minority rule" courts as the grounds of decision in automobile guest passenger cases.

After the decision in Coggs $v$. Bernard in 1703, bailments remained a distinct legal subject matter for about 200 years. Three published works comprise the fundamental texts for the entire period: Lord Holt's opinion itself; Sir William Jones's essay; ${ }^{26}$ and Justice Story's treatise. ${ }^{27}$ Lord Holt's conception that a less than ordinary duty of care should be imposed upon a gratuitous bailee was incorporated in Story's treatise ${ }^{28}$ and, more importantly, was put into practice by the courts. In the leading Massachusetts case of Foster v. Essex Bank, ${ }^{29}$ for example, a gratuitous bailee was exonerated from liability for ordinary negligence, even though the bailee

26 JoNES ON BAILMENTS, supra note 21.

${ }^{27}$ STORY ON BalLMENTs, supra note 18.

28 Id. 523, at 27 .

${ }^{29} 17$ Mass. 479 (1821). Captain Israel Foster had left with the Essex Bank $\$ 53,000$ worth of gold coin. The transaction was a "special deposit," i.e., a simple deposit of goods for safekeeping, rather than a "general deposit," which would have authorized the bank to treat the coins as money which it could loan out or otherwise make use of. No charge was made for accepting the deposit, and it appears to have been undertaken purely as an accommodation to Captain Foster, who was a stockholder in the bank. Over a number of years, two bank employees embezzled the greater part of the bank funds, including nearly all of Captain Foster's gold. The bank's bookkeeping methods were evidently inadequate. On the other hand it was unquestioned that the bank had taken as diligent care of Captain Foster's gold as it had of its own. The loss was discovered after Captain Foster's death, and an assumpsit for $\$ 50,000$ had and received was brought by his executors.

It is noteworthy, in tracing the doctrine of degrees of care, that the arguments and the decision of this case were based primarily on the authorities of Justinian, Bracton, Coggs $v$. Bernard, and Sir William Jones. An excerpt from Chief Justice Parker's opinion shows how much the gratuitous bailment doctrine had retained its original form.

It will not be disputed, that, if [the transaction] amounts only to a naked bailment, without reward, and without any special undertaking, which, in the civil and common law is called Depositum, the bailee will be answerable only for gross negligence, which is considered equivalent to a breach of faith: as every one, who receives the goods of another in deposit, impliedly stipulates that he will take some degree of care of it. The degree of care, which is necessary to avoid the imputation of bad faith, is measured by the carefulness which the depositary uses toward his own property of a similar kind. For although that may be so slight, as to amount even to carelessness in another; yet the depositor has no reason to expect a change of character, in favor of his particular interest; and it is his own folly to trust one, who is not able, or willing, to superintend with diligence his own concerns.

This principle, although denied by Lord Coke . . . has been received as the law regulating gratuitous bailment ... from the luminous opinion of Lord Holt in the celebrated case of Coggs $v$. Bernard, down to the profound and brilliant treatise of Sir William Jones . . . .

17 Mass. at 498-99. 
was a bank and the bailment was a keg of gold doubloons deposited for safekeeping.

But the impact of Coggs extended far beyond the law of bailments. The most fundamental contribution to the common law made by Lord Holt's opinion was its delineation of the varying degrees of care which might be legally owed by one person to another. This concept is most apparent in modern tort law in the distinction between ordinary and gross negligence, which is a logical consequence of recognizing varying degrees of care. ${ }^{30} \mathrm{In}$ analyzing the duties of bailees in Coggs, Lord Holt distinguished between slight care (e.g., that owed by the purely gratuitous bailee), ordinary care (e.g., that owed by the pledgee), and extraordinary care (e.g., that owed by the recipient of a gratuitous loan for his benefit). ${ }^{31}$ The logical converse of these three degrees of care is three degrees of lack of care, or negligence, for which liability may be imposed. Thus, where there is a duty of extraordinary care, there will be liability even for slight negligence; where there is a duty of ordinary care, there will be liability for negligence; and where there is a duty of only slight care, there will be liability only for gross negligence.$^{32}$ In its full tripartite form, this scheme was probably derived from Roman law. ${ }^{33}$

The idea of gross negligence became increasingly controversial during the nineteenth century as some judges grew impatient with the distinctions it required to be drawn..$^{34}$ Both the doctrine of de-

${ }^{30}$ See generally W. Prosser, The LaW of Torts 183-86 (4th ed. 1971).

"s See note 21 supra. Jones and Story, more systematic than Lord Holt, both began their works on bailments with a precise delineation of the arrangement. JONES ON BAILMENTS, supra note 21, 5-23; STORY ON BAILMENTS, supra note 18, $\$$ 11-22, at 14-27.

32 "The use of the term gross negligence is only one way of stating that less care is required in some cases than in others, as in the case of gratuitous bailees, and it is more correct and scientific to define the degrees of care than the degrees of negligence." Grill v. General Iron Screw Collier Co., L.R. 1 C.P. 600, 614 (1866) (Montague Smith, J.).

${ }^{3}$ Some authorities on Roman law believe that the three degrees of negligence (or culpa) were postclassical. See W. Buckland, The Main Institutions of Roman Private Law 300-03 (1931). Modern opponents of the doctrine of degrees of care have castigated Jones and Story for their assumption that the tripartite scheme had full classical authority. Article, The Three Degrees of Negligence, 8 Am. L. Rev. 649 (1874); Green, High Care and Gross Negligence, 23 ILL. L. REv. 4, 12-14 (1928). But the concept of slight, ordinary, and gross negligence (levissima, levis, and lata culpa) was an accepted doctrine of civil law long before its enunciation by Sir William Jones; if it was not the classical Roman law, it was what Holt, Jones, and Story thought that law to be. See, e.g., Story on BaILments, supra note 18, $\$ 18$, at 21 n.2 (quoting the synopsis by Heineccius). Story's footnote indicates some of what were taken to be the Roman sources for the generalization.

3t The famous bon mot of Baron Rolfe, that "I said I could see no difference between negligence and gross negligence-that it was the same thing, with the addition of a vituperative epithet," Wilson v. Brett, 11 M. \& W. 113, 115-16, 152 Eng. Rep. 737, 739 (Ex. 1843), came to be quoted in support of the assertion that the attempted distinction was one without 
grees of care and the concept of gross negligence survived their nineteenth century opponents, however, and the 1873 opinion of Justice Bradley in New York Central R.R. v. Lockwood ${ }^{35}$ is a ringing endorsement of the doctrine.

The theory of degrees of care and the corresponding liability for different degrees of negligence were abstracted from the bailments context and generalized at least as early as Sir William Jones's treatise. Jones made explicit what Lord Holt had left to inference: that the duty of care imposed is proportional to the benefit conferred. ${ }^{36}$ By the time the courts considered the first automobile guest passenger cases, this generalized theory of degrees of care, cut loose from any attachment to the law of bailments, had been applied to cases involving guest passengers in horse-drawn vehicles. Moffat $v$.

meaning. Although he chose to quarrel with the terminology, the context of Baron Rolfe's observation shows that he fully understood and in large part approved the distinction among degrees of care which the words "gross negligence" reflect. Wilson v. Brett involved the gratuitous bailment of a horse. "The distinction I intended to make was, that a gratuitous bailee is only bound to exercise such skill as he possesses, whereas a hirer or borrower may reasonably be taken to represent to the party who lets, or from whom he borrows, that he is a person of competent skill. If a person more skilled knows that to be dangerous which another not so skilled as he does not, surely that makes a difference in the liability. I said I could see no difference . . . and I intended to leave it to the jury to say whether the defendant, being, as appeared by the evidence, a person accustomed to the management of horses, was guilty of culpable negligence." Id.

The leading American case disparaging the distinction between degrees of negligence is The Steamboat New World v. King, 57 U.S. (16 How.) 469 (1853). "The theory that there are three degrees of negligence, described by the terms slight, ordinary, and gross, has been introduced into the common law from some of the commentators on the Roman law. It may be doubted if these terms can be usefully applied in practice. Their meaning is not fixed, or capable of being so. One degree, thus described, not only may be confounded with another, but it is quite impracticable exactly to distinguish them." Id. at 474.

${ }^{35} 84$ U.S. (17 Wall.) 357 (1873). In this case the Supreme Court stated:

We have already adverted to the tendency of judicial opinion adverse to the distinction between gross and ordinary negligence. Strictly speaking, these expressions are indicative rather of the degree of care and diligence which is due from a party and which he fails to perform, than of the amount of inattention, carelessness, or stupidity which he exhibits. . . . If the opponents of gross negligence mean more than this, and seek to abolish the distinction of degrees of care, skill, and diligence required in the performance of various duties and the fulfillment of various contracts, we think they go too far; since the requirement of different degrees of care in different situations, is too firmly settled and fixed in the law to be ignored or changed. The compilers of the French Civil Code undertook to abolish these distinctions by enacting that "Every act whatever, of man, that causes damage to another, obliges him by whose fault it happened to repair it." Art. 1382. Toullier, in his commentary on the code, regards this as a happy thought, and a return to the law of nature. . . . But such an iron rule is too regardless of the foundation principles of human duty, and must often operate with great severity and injustice. Id. at 382-83.

${ }^{36}$ Jones on Bailments, supra note 21, at 22-23; cf. StoRy on Bailments, supra note 18, $\S 23$, at 27 . 
Bateman, ${ }^{37}$ a case involving a buggy which overturned on a dirt road in Australia, was appealed all the way to the Privy Council. According to Lord Chelmsford, the threshold question in the case was the degree of care the driver had owed to his passenger. The court found the transaction wholly gratuitous and held that the driver therefore owed a duty of only slight care. Since there was no evidence of gross negligence, the driver could not be found liable. ${ }^{38}$ The word "bailee" does not appear in the opinion. Lord Chelmsford's rhetorical question shows the extent to which the benefit-conferred analysis of bailments had been generalized to indicate degrees of care in analogous situations: "Is there, then, any evidence of the Appellant having been guilty of gross negligence-a term which is sufficiently descriptive of the degree of negligence which renders a person performing a gratuitous service for another, responsible?" ${ }^{39}$ The concept of degrees of care now constituted the fundamental proposition; and any mention of bailment, in a nonbailment case, would serve only as a convenient reference to the origins of the doctrine.

In West $v$. Poor ${ }^{10}$ the Massachusetts court provided a very similar precedent. A little girl who had hitched a ride on a milk wagon was injured as she was getting out. Considering the child's status, the court found that she resembled either a licensee or the beneficiary of a gratuitous bailment. In either case the duty of the driver was held to be one of slight care only. ${ }^{41}$ The court's indifference to whether the situation more closely resembled a license or a bailment shows that the assessment of the proper degree of care was now its primary consideration, the references to licenses and bailments serving more as illustrative analogies than as terms of analysis.

\section{Automobile Guest Passenger Cases at Common Law}

When cases involving automobiles came before the courts, the common law developed two different rules for determining the liability of a driver to a guest passenger. The rule followed by a minor-

${ }^{37}$ L.R. 3 P.C. 115 (1869)

${ }^{38} I d$. at $121-22$.

39 Id. at 122 .

so 196 Mass. 183,81 N.E. 960 (1907).

"In the former case the degree of care required is that of a licensor and licensee ...., which, as has often been said, requires only that the licensor shall not set traps for the licensee and shall refrain from reckless, willful, or wanton misconduct tending to injure him. . . . In the latter case, in order to render the bailee liable, it must appear that he has been guilty of culpable negligence. . . . If the standard of care required was that of a licensor or gratuitous bailee, as we think it was, it is entirely plain that there was no breach of duty on the part of the defendant.

Id. at 185,81 N.E. at 960 (citations omitted). 
ity of jurisdictions originated in Massaletti $v$. Fitzroy, ${ }^{42}$ where the Massachusetts Supreme Court held that a driver was liable only for gross negligence toward his guest passenger, analogizing the standard of care owed by a host driver to that owed by a gratuitous bailee. Massaletti reaffirmed such cases as Moffat and West and, through them, the doctrine of varying duties of care which had arisen with the common law learning on bailments beginning in Coggs v. Bernard.

The plaintiff in Massaletti was riding as the guest of the defendant in an automobile operated by defendant's chauffeur when the car hit a post and overturned. It was accepted on appeal that the evidence at trial had been sufficient to show negligence, but not gross negligence, on the part of the chauffeur. ${ }^{43}$ The Massachusetts court affirmed a directed verdict for the defendant. An exhaustive opinion by Justice Loring contains several points of particular importance.

The court rejected a line of cases advanced by the plaintiff, which had compared the driver/passenger relation to that of licensor/licensee, holding a driver liable if by his "active negligence" he increased a present danger or created a new one during the period of the "license." 4 It is true that in West $v$. Poor the same court had suggested the licensor/licensee relation as one possible analogy for the driver/guest passenger situation, but in West the "active negligence" argument had not been confronted. In Massaletti, the court avoided the logic by which negligent driving was held to constitute "increasing the danger" by rejecting the license analogy altogether: "[W]here a defendant invites a plaintiff to ride gratis in his car-

12228 Mass. 487,118 N.E. 168 (1917).

${ }^{13}$ Id. at 489,118 N.E. at 168.

st The "increasing the danger" argument originated with Pigeon v. Lane, 80 Conn. 237, 67 A. 886 (1907) and was more fully developed by Patnode v. Foote, 153 App. Div. 494, 138 N.Y.S. 221 (1912).

A person thus invited to ride stands in the same situation as a bare licensee who enters upon real property which the licensor is under no obligation to make safe or keep so, but who is liable only for active negligence. . . . Under the above principles, therefore, one who invites another to ride is not bound to furnish a sound vehicle or a safe horse. If he should have knowledge that the vehicle was unfit for transportation or the horse unsafe to drive, another element would arise . . . . These latter elements, however, are not involved in the present action, and the duty of the defendant toward the plaintiff only was to use ordinary care not to increase the danger of her riding with him or to create any new danger.

153 App. Div. at $495-96,138$ N.Y.S. at $222-23$. The analysis presents some logical difficulties. If the negligent host is not obliged to furnish a sound vehicle or a safe horse, why is he obliged to furnish a careful driver, i.e., one more prudent than himself? The negligence of the driver is not a "new" danger when an accident occurs, but a continuing danger inherent in accepting his hospitality. 
riage, the question is not a question of the measure of liability of a licensor to a licensee. It is the question of the measure of the liability assumed in a case of a gratuitous undertaking." 45 Thus, using language strikingly similar to that of Lord Chelmsford in Moffat $v$. Bateman, the court accepted the implication of that opinion that any gratuitous undertaking, not only bailments, will impose different duties of care from one that is compensated.

After recognizing the distinction between gross and ordinary negligence ${ }^{46}$ - the logical converse of slight and ordinary care-the court set out to support its central contention, that "the measure of liability of one who undertakes to carry gratis is the same as that of one who undertakes to keep gratis." 47 The argument, in part, deals with the appropriate level of duty to be imposed by a mandate, Lord Holt's sixth classification of bailments; ${ }^{48}$ in part, it appeals to English precedents. ${ }^{49}$ The central point drawn from these authorities is that the gratuitous nature of an undertaking, by itself,

${ }^{15} 228$ Mass. at 492,118 N.E. at 170 . The court stressed the same point later in the opinion in distinguishing the cases on duties of property owners as irrelevant.

Whether one invited to come on to the defendant's premises for his (the invitee's) purposes alone takes them as he finds them or can hold the defendant for negligence in case the premises are in a dangerous condition, is a question of the obligation assumed by one inviting another to come upon his land; while the extent of the obligation assumed by inviting one to travel gratis in the invitor's carriage is a question of the liability of one who enters upon a gratuitous undertaking whether it be a gratuitous undertaking to keep, carry, or lend.

Id. at 508,118 N.E. at 176.

"Id. at 501-02, 118 N.E. at 174 .

17 Id. at 508,118 N.E. at $176-77$.

1* If the actual transportation of a gratuitous passenger is to be likened to one of Lord Holt's six categories of bailments, it seems most like the sixth, the "mandate" or commission, which is the bailment to receive something and take it somewhere or do something about it. The notorious difficulty of deciding the appropriate standard of diligence for this bailee, the mandatary, has been mentioned earlier. See note 21 supra. There are persuasive logical reasons and scholarly authority for the view that the mandatary's duty, like that of the simple gratuitous bailee, is of slight care only. Justice Loring explicates the question and marshals this side of the argument ably. 228 Mass. at 502-06, 118 N.E. at 174-75. It requires no antiquarian interest, however, to perceive the basic point that if duties are to be imposed to the extent that there is benefit conferred, the purely gratuitous mandatary will owe the minimum degree of care.

19 It would seem that in England the liability of a gratuitous bailee and the liability of one who undertakes a gratuitous transportation is the same. And to this one thing more must be added, namely: However much the English judges have quarreled with the meaning of the words gross negligence, it is the fact that when pushed to a decision the judges of England have invariably held that to make out liability in case of a gratuitous undertaking (no matter what the nature of the gratuitous undertaking was) gross negligence has to be made out.

228 Mass. at 506, 118 N.E. at 176, citing Giblin v. McMullen, L.R. 2 P.C. 317, 336-37 (1869) (Chelmsford, L.J.) (the leading nineteenth century English opinion on degrees of care), Moffat v. Bateman, L.R. 3 P.C. 115 (1869), and Coughlin v. Gillison, [1899] 1 Q.B. 145. 
justifies imposing a lower level of duty than that imposed in a compensated transaction. ${ }^{50}$

In conclusion, the court, "[a]pproaching the question apart from authority," expressed its own view of the equitable and practical considerations in the case:

Justice requires that the one who undertakes to perform a duty gratuitously should not be under the same measure of obligation as one who enters upon the same undertaking for pay. There is an inherent difficulty in stating the difference between the measure of duty which is assumed in two cases. But justice requires that to make out liability in cases of a gratuitous undertaking the plaintiff ought to prove a materially greater degree of negligence than he has to prove where the defendant is to be paid for doing the same thing. It is a distinction which seventy-five years' practice in this Commonwealth has shown is not too indefinite a one to be drawn by the judge and acted upon by the jury. ${ }^{51}$

This was to become the policy "rationale" of automobile guest statutes.

Massaletti $v$. Fitzroy was the zenith of common law analysis of the automobile guest problem. None of the state courts that followed it to form the minority rule contributed original theory. Their concurrence simply shows that the Massaletti rationale, although a minority view, had the support of a recognizable body of judicial opinion. Six states in addition to Massachusetts decided on common law grounds to limit in some respects a driver's liability to his guest passenger. ${ }^{52}$

${ }_{50}$ The court also pointed out that what conduct may constitute any of the various levels of care will depend on the subject matter of the transaction. Slight care in the transportation of a human passenger is more care than slight care about a block of wood. 288 Mass. at 507, 118 N.E. at 176.

sl Id. at 510, 118 N.E. at 177. Justice Story made a similar observation.

It would be very difficult, indeed, to persuade any civilized community that a depositary should be liable for every loss, and bound to the same vigilant care of the deposit, as a borrower for his own exclusive benefit; or that a mandatary, who, from mere kindness, gives his services to his friend, should have the same responsibility fastened on him as a carrier for hire, who stipulates and receives a suitable and adequate reward for his services and his vigilance. And it will accordingly be found that, in the most polished as well as in the least refined of nations, whether ancient or modern, distinctions in degrees of responsibility have been adopted, in all these classes of cases, with a surprising uniformity.

StoRy ON Bailments, supra note $18, \S 10$, at 14 .

52 The other leading cases representing the minority rule may be divided into two categories: those explicitly following Massaletti on degrees of care and those employing a form of "licensee" analysis. 
The majority of jurisdictions rejected the Massaletti rule and held that the automobile driver owed his guest passenger a duty of ordinary care-the same duty owed to such strangers as pedestrians and other drivers. ${ }^{53}$ Most courts reaching this result ignored the niceties of the doctrine of degrees of care. But the more thoughtful decisions, most notably Avery $v$. Thompson, ${ }^{54}$ demonstrated that a common law court taking account of the degrees of care analysis could nevertheless find that considerations arising from the substantive nature of the undertaking outweighed those considerations

(1) The Massaletti line of cases are the following:

Cody v. Venzie, $263 \mathrm{~Pa} .541,107 \mathrm{~A} .383$ (1919), closely resembles an abbreviated Massaletti. The court traced the origins of the doctrine of degrees of care from Coggs $v$. Bernard, noting that the doctrine had been repeatedly approved in Pennsylvania, and concluded that "from the well settled law on the subject of bailments we may ascertain and define the duty which the gratuitous carrier owes his guest [quoting STORY ON BAiLMENTS, supra note $18, \S 23]$. . . . It follows, therefore, that when a gratuitous carriage is for the sole benefit of the guest, the law requires slight diligence and makes the carrier only responsible for gross neglect." Id. at 546, $107 \mathrm{~A}$. at 385.

The court in Epps v. Parrish, 26 Ga. App. 399, 106 S.E. 297 (1921), adopted Massaletti as an authoritative precedent without discussion.

In Heiman v. Kloizner, 139 Wash. 655, 247 P. 1034 (1926), the court recognized "varying degrees of negligence, or varying degrees of required care" as "a practicable working principle of the law of this state." Id. at 659-60, 247 P. at 1036 (quoting Massaletti at length and with approval). The decision was reaffirmed en banc in Saxe v. Terry, 140 Wash. 503, 250 P. 27 (1926), which is the Washington case more frequently cited.

In Boggs v. Plybon, 157 Va. 30, 160 S.E. 77 (1931), the court reaffirmed the validity of the doctrine of degrees of care. The court quoted extensively from Massaletti, adding that "[to] hold that a guest who, for his own pleasure, is driving with his host may recover from him for injuries suffered where there is no culpable negligence, shocks one's sense of justice." Id. at 39,160 S.E. at 81.

(2) In contrast, the following minority rule cases were based on a "licensee" analysis:

Lutvin v. Dopkus, 94 N.J.L. 64, 108 A. 862 (Sup. Ct. 1920), presented facts tending to show negligence or "increasing the danger." The defendant had driven at a high rate of speed until his car overturned. In affirming a verdict for the defendant, the court found that "the legal status of the plaintiffs here exhibited is that of licensees to whom the only legal obligation imposed is that of refraining from the perpetration of acts wantonly or willfully inju. rious." Id. at $66,108 \mathrm{~A}$. at 863 .

The court in Cleary v. Eckart, 191 Wis. 114, 210 N.W. 267 (1926), adopted the formulation of a duty "not to increase the danger" from Patnode v. Foote, 153 App. Div. 494, 138 N.Y.S. 221 (1912) (see note 44 supra), but took a more restrictive view of the consequences. The court quoted from Patnode the statement that "one who invites another to ride is not bound to furnish a sound vehicle or a safe horse," and continued: "Similarly we think that one who asks another to ride with him in his automobile does not guarantee to the guest a sound automobile or an accomplished degree of skill in the management thereof. His duty extends only to refraining from increasing the danger which the guest assumes upon entering the automobile manned by the driver provided . . . "Id. at 120,210 N.W. at 269 .

${ }^{53}$ The growth of the majority rule of liability may easily be traced through Annot., 20 A.L.R. 1014 (1922); Annot., 26 A.L.R. 1425 (1923); Annot., 40 A.L.R. 1338 (1926); Annot., 47 A.L.R. 327 (1927); Annot., 51 A.L.R. 581 (1927); Annot., 61 A.L.R. 1252 (1929); and Annot., 65 A.L.R. 952 (1930).

st 117 Me. 120, 103 A. 4 (1918). 
flowing from its gratuitous character ${ }^{55}$ Courts which have ignored the latter half of this balance of considerations have failed to come to grips with the full extent of the legal problem. The purpose of this discussion of the minority and majority rules has been not to decide the question as a matter of common law, but to demonstrate that the view adopted in Massaletti $v$. Fitzroy is rational, logically defensible, and based on two centuries of rational precedent.

\section{The Adoption of the Minority Rule by State Legislatures}

Confronted by two conflicting rules of law on the duty of care owed by drivers to guests, the legislatures of approximately half the states ${ }^{56}$ chose to replace the majority rule prevailing in their jurisdictions with the minority rule of Massaletti and its progeny. Unlike legislation drafted a priori, the new enactments carried with them an established ancestry of judicial interpretation. To this extent the rationale of the common law decisions which they incorporated may be imputed to the statutes; and their "purpose" may be identified with the "purpose" of the judicial decisions-that purpose being, presumably, to promote one ordering of society over an alternative because the disposition favored was perceived to be the more just. ${ }^{57}$ As one contemporary commentator noted:

The Massaletti decision commanded widespread attention and approval. It was supported by certain fundamental attributes of fairness and justice and its popularity may be well understood. Hence, it was but reasonable that legislatures seeking to make their motor vehicle legislation as comprehensive as possi-

35 Having set forth the problem in terms of degrees of care, the court observed, "[W]e think that the true rule of liability on the part of a voluntary undertaker should be this, that he be required to exercise that degree of care and caution which would seem reasonable and proper from the character of the thing undertaken." Id. at 124, 103 A. at 6 . In this view, the voluntary undertaking carries with it the voluntary assumption of a corresponding obligation of care.

${ }^{56}$ See note 1 supra.

57 The "rationale" of automobile guest statutes is, ultimately, the rationale of Coggs $v$. Bernard. This prestatute "majority rule" of liability to guest passengers rests on the same logic as Southcote's Case. By his assumption of the gratuitous undertaking, the driver was held to have assumed the duty as well-there being only one allowable level of duty. The "minority rule," by contrast, operated by analogy to Coggs $v$. Bernard, seeking to impose only that level of duty which would be appropriate to the relative status of the parties and the gratuitous nature of the transaction. "Minority rule" courts preferred this disposition of the problem, just as the King's Bench in 1703 had preferred its disposition of Coggs $v$. Bernard to the earlier treatment of Southcote's Case. The "rationale" is no more and no less than this preference. 
ble, eventually should undertake to reduce the rule to statutory form..$^{58}$

Further evidence that the guest statutes were adopted from the common law tradition may be found in the decisions upholding the validity of the new statutes against constitutional challenge. Connecticut's statute ${ }^{59}$ offers a good example, since it was one of the first to be enacted, was the first to be challenged, and was ultimately upheld by the Supreme Court in that Court's only decision on the question. ${ }^{60}$

Prior to the enactment of the statute, the Connecticut courts had followed the "majority rule" on automobile guest passengers. The state's leading case on the subject ${ }^{61}$ expressly disapproved the argument of Massaletti and the theory of degrees of care, holding a driver liable for the exercise of "due care" measured by the standard of "the reasonably prudent person." 62 Reversing this common law rule, the Connecticut statute denied a cause of action to the injured guest passenger "unless such accident shall have been intentional on the part of said owner or operator or caused by his heedlessness or his reckless disregard of the rights of others." 63 The rule of Massaletti was now effectively law in Connecticut.

The statute was challenged in the Connecticut Supreme Court of Errors on the ground that it was based on an unreasonable classification and therefore denied automobile guests the equal protection of the laws. ${ }^{64}$ Examining the central classification imposed by the statute, the court found it neither arbitrary nor unreasonable. The court's justification is drawn straight from Massaletti.

The statute imposes upon the owner or operator of a motor vehicle a different degree of care toward a guest than he is required at common law to exercise toward a passenger who pays for his transportation. Such a distinction between the duty imposed in the case of the gratuitous performance of services and the performance of them for hire is to be found running

sx Elliott, Degrees of Negligence, 6 S. CAL. L. Rev. 91, 133 (1933).

59 Ch. 308, §§ 1-2, [1927] Conn. Acts 4404 (repealed 1937).

so Silver v. Silver, 280 U.S. 117 (1929).

s Dickerson v. Connecticut Co., 98 Conn. 87, 118 A. 518 (1922).

s2 Id. at 91,118 A. at 519.

s3 Ch. 308, § 1, [1927] Conn. Acts 4404 .

" Silver v. Silver, 108 Conn. 371, 143 A. 240 (1928). The facts make Silver a paradigm case. The plaintiff was the wife of the driver. The accident was caused by the driver's momentary inadvertence in looking away from the road when his son, in the back seat, called out, "Oh, Daddy, look at the horses!" The defendant received a directed verdict on the ground that such conduct did not constitute "heedlessness or reckless disregard." 
through many fields of the law, as for example between the gratuitous bailee and the bailee for hire, the common carrier and the private driver, the innkeeper and the ordinary social host. In some jurisdictions it is held that the owner or operator of a motor vehicle is liable to a guest only in the case of gross negligence, in analogy to the rule prevailing in the case of a gratuitous bailment of goods [citing Massaletti]. There is inherent justice in the requirement that one who undertakes to perform a duty gratuitously should not be under the same measure of obligation as one who enters upon the same undertaking for pay, and the reason for a distinction between the measure of liability in the case of a gratuitous bailment and gratuitous transporation is not obvious. ${ }^{65}$

The decision was affirmed by the United States Supreme Court. ${ }^{66}$ There the Massaletti rationale was mentioned briefly as one of several policy considerations which might have influenced the legislature.$^{67}$ In rejecting the constitutional challenges subsequently brought against the guest statutes of other states, most courts referred to the two Silver $v$. Silver decisions as authority, and some referred expressly to Massaletti as well. ${ }^{68}$

\section{The Constitutionality of Automobile Guest Statutes}

The "second wave" of constitutional challenges to guest statutes, following the lead of Brown v. Merlo, has sought to measure the statutes by equal protection standards. Courts have thus attempted to analyze and evaluate the supposed purposes of guest statutes, to identify the "classifications" imposed by the statutes, and to examine the relationship between purposes and classifications. ${ }^{69}$ Recent opinions both upholding and invalidating guest statutes have performed these three tasks inadequately.

First, courts have assumed that the purposes of guest statutes are to promote hospitality and to prevent collusive lawsuits, ignor-

${ }^{85}$ Id. at $378-79,143$ A. at 243.

${ }^{66}$ Silver v. Silver, 280 U.S. 117 (1929).

67 "In some jurisdictions it has been judicially determined that a lower standard of care should be exacted where the carriage in any type of vehicle is gratuitous." 280 U.S. at 123, citing Massaletti v. Fitzroy, 228 Mass. 487, 118 N.E. 168 (1917).

${ }^{6 \times}$ Cases referring to Massaletti include: Roberson v. Roberson, 193 Ark. 669, 101 S.W.2d 961 (1937); Naudzius v. Lahr, 253 Mich. 216, 234 N.W. 581 (1931); and Perozzi v. Ganiere, 149 Ore. 330, 40 P.2d 1009 (1935). Early cases upholding the constitutionality of guest statutes on various grounds are collected in Annot., 111 A.L.R. 1011 (1937). Naudzius v. Lahr is the fullest opinion of the post-Silver cases and the one most frequently cited.

${ }^{69}$ See cases cited at note 52 supra. 
ing the rationale suggested by an examination of the legal-historical background of the statutes: a legislative preference for the flexible common law doctrine of degrees of care as the more just approach to ordering obligations between automobile drivers and their passengers. ${ }^{70}$

This rationale is not merely another form of the "protection of hospitality" hypothesis. There is admittedly a thematic connection between the ideal of "protection of hospitality" and the sense of natural justice that suggests that one who undertakes a gratuitous action should not bear the same liability as one who is compensated. But the connection is superficial only. "Protection of hospitality" is at best a transitory objective of social policy, and it was so treated in Brown v. Merlo. The court found in "protection of hospitality" a legislative condemnation of the injured guest's "ingratitude" in suing his host: ${ }^{71}$ it then found that such "ingratitude" had been rendered harmless by the interposition of liability insurance. ${ }^{72}$

Compared to the full breadth of the doctrine of degrees of care, however, this treatment of "protection of hospitality" is essentially trivial. The common law doctrine is not concerned with "ingratitude," nor are its objectives served by liability insurance. Rather it embodies a fundamental theory about the nature of civil obligations: one which deals with the just imposition of obligations, rather than (as in theories of loss spreading or cost avoidance) the practical consequences of their discharge or fulfillment. The question is no longer "is it necessary?" or "does it work?" but "is it right?"

Given its historical background, the doctrine of degrees of care can scarcely be "arbitrary"; it seems unlikely that it could be "essentially unreasonable." Indeed, to some extent at least, the doctrine still reflects what natural justice would seem to require. ${ }^{73}$ The

${ }^{70}$ In a footnote the Brown v. Merlo opinion does make passing reference to Massaletti and the theory of degrees of care; but the reference is depreciatory and scarcely constitutes a serious treatment of the issues raised. 8 Cal. $3 \mathrm{~d}$ at $858 \mathrm{n} .1,506 \mathrm{P} .2 \mathrm{~d}$ at $214 \mathrm{n} .1,106 \mathrm{Cal}$. Rptr. at $390 \mathrm{n} .1$. Whereas the Massaletti opinion was the culmination of a lengthy common law development, the footnote cited suggests that the degrees-of-care rationale "appears to have originated with the 1917 Massaletti decision"; the note further observes that "Massaletti never obtained a following among sister jurisdictions, but in fact seems to have met nearuniversal judicial condemnation." As to Massaletti's "following among sister jurisdictions," see note 52 supra. What is more important is that Massaletti met with the approval of the legislatures in California and elsewhere, and that their enactments met with near-universal judicial support. Here, as elsewhere, the Brown $v$. Merlo opinion tends to obscure the distinction between the legislative and judicial functions.

$" 8$ Cal. 3d at 867 n.8, 506 P.2d at 221 n.8, 106 Cal. Rptr. at 397 n.8.

72 "In plain language, there is simply no notion of 'ingratitude' in suing your host's insurer." Id. at 868, 506 P.2d at 221, 106 Cal. Rptr. at 397.

73 The ethical presumption of Massaletti, that "one who undertakes to perform a duty 
guest statutes embody this common law doctrine; and they are no more susceptible than the doctrine itself to a generalized charge of irrationality.

Second, some recent opinions have inadequately identified the relevant classifications imposed by guest statutes. The court in Brown v. Merlo initiated the confusion by discerning in the California guest statute "three distinct levels of classification or discrimination." "The statute was said to distinguish, first, between guests and paying passengers in automobiles; second, between automobile guests and "other social guests and recipients of 'generosity" "; and third, between "different subclasses of automobile guests, witholding recovery from those guests injured while 'in a vehicle' 'during a ride' 'upon a public highway,' but permitting recovery by auto guests injured in other circumstances."75 Only the first "classification"-that between guests and paying passengers-is directly imposed by a guest statute. The court's second "classification," between automobile guests and other social guests, rests on the unstated argument that distinctions imposed by legislation in a given area of activity must be correspondingly imposed in every area of activity found to be analogous. ${ }^{76}$ Precisely this argument against automobile guest statutes was rejected by the Supreme Court in Silver $v$. Silver. ${ }^{77}$ The Supreme Court, moreover, has adhered to the

gratuitousiy should not be under the same measure of obligation as one who enters upon the same undertaking for pay," cannot be dismissed out of hand. It might of course be held to be outweighed by competing social needs.

"4 8 Cal. 3d at 863, 506 P.2d at 217, 106 Cal. Rptr. at 393.

${ }^{25}$ Id.

${ }^{76}$ Noting that the common law distinctions between duties of care owed by a landowner to his guests and business visitors had recently been abolished in California in Rowland v. Christian, 69 Cal. 2d 108, 443 P.2d 561, 70 Cal. Rptr. 97 (1968), the court in Brown v. Merlo discerned an untenable "classification" in the distinction between automobile guests and the "other social guests and recipients of 'generosity" " whose causes of action for ordinary negligence it had recently confirmed. 8 Cal. 3d at 869-70, 506 P.2d at 222-23, 106 Cal. Rptr. at 398-99. Actually, the existence of an analogous common law doctrine on duties of landowners tends to support rather than to undermine the "rationality" of the guest/paying passenger distinction. A court may legitimately reverse the one rule and not the other, precisely because the former is judge-made law, while the latter is statute.

${ }^{77}$ The court in Brown v. Merlo sought to distinguish Silver v. Silver on the ground that the Supreme Court had addressed only the distinction between automobile guests and guests in other conveyances, and not the distinction between paying and guest passengers. 8 Cal. $3 \mathrm{~d}$ at 863 n.4, 506 P.2d at 217 n.4, 106 Cal. Rptr. at 393 n.4. On the contrary, the rationality of the obvious distinction between paying and guest passengers appears to have been conceded by petitioners in Silver $v$. Silver, who attempted rather to distinguish another classification in the statute which might be found invidious. "It is said that the vice in the statute is not that it distinguishes between passengers who pay and those who do not, but between gratuitous passengers in automobiles and those in other classes of vehicles." 280 U.S. at 123. In the preceding paragraph of the opinion the paid/gratuitous distinction had been noticed 
view that the legislature is not faced with such an "all or nothing" choice in regulating a particular area. ${ }^{78}$ The final "classification" identified by the California court, "between different subclasses of automobile guests," seems almost disingenuous. By this line of argument the court simply imputed to the statutory scheme the eccentricities in its application which were the result of the court's own prior decisions taking certain cases out of the statute. ${ }^{79}$

What remains is the analytical core of the guest statute problem, the "classification" of guests and paying passengers: in other words, the distinction between gratuitous and paid transportation. The distinction between activity that is gratuitous and activity that is compensated is not only "rationally related" to the statutes' purpose-recognition of degrees of care-it is in a sense identical with that purpose.

by the Court as one objective of the statute. "In some jurisdictions it has been judicially determined that a lower standard of care should be exacted where the carriage in any type of vehicle is gratuitous [citing cases]." Id. Petitioners tried to emphasize alternative "classifications" before the Supreme Court because the central, paid/gratuitous distinction had been extensively treated, and squarely upheld, in the decision under review. Silver v. Silver, 108 Conn. 371, 143 A. 240 (1928). See text at note 65 supra.

${ }^{7 x}$ E.g., Jefferson v. Hackney, 406 U.S. 535, 546 (1971); Williamson v. Lee Optical Co., 348 U.S. 483,489 (1955).

7 Restrictive judicial interpretations which might be read as creating unreasonable classifications are quite common. See note 3 supra. The California Supreme Court, for instance, had increasingly narrowed the scope of the guest statute. The court had held the statute inapplicable where the "ride" was momentarily interrupted to inspect the vehicle's tires; where the passenger was on the running board of the car rather than inside it; and where the vehicle was on a private road rather than a public highway. In Brown v. Merlo, the court found that these distinctions bore no rational relation to the purposes of the statute, but rather served to render its operation "erratic and fortuitous." 8 Cal. 3d at 879, 506 P.2d at 229,106 Cal. Rptr. at 405. (In a footnote the court stated, "We reject the contention that this irrationality has been manufactured by judicial interpretation." 8 Cal. $3 \mathrm{~d}$ at $880 \mathrm{n} .20,506$ P.2d at 230 n.20, 106 Cal. Rptr. at 406 n.20.)

One of the circumstantial distinctions attacked in Brown v. Merlo-between injuries suffered on "private roads" and on "public highways"- had been read into the law by the same court only five years before. O'Donnell v. Mullaney, 66 Cal. 2d 994, 429 P.2d 160, 59 Cal. Rptr. 840 (1967). There the court had managed to find that in the section of the Vehicle Code which contained the guest statute, the word "highway" meant a public highway exclusively; whereas in another section of the same Vehicle Code, dealing with service of process, the word "highway" included private roads. See Comment, Judicial Nullification of Guest Statutes, 41 S. CAL. L. REv. 884 (1968). Defendants in O'Donnell v. Mullaney appear to have raised the equal-protection objection which the court would adopt in Brown v. Merlo:

Defendants' final argument is that the suggested result creates an unconstitutional distinction between the obligations of one who is an automobile host on a highway and one in the same status on a private road. That contention is without merit. The legislature has wide discretion in making a classification, and its exercise in this instance does not distinguish among persons of like conditions and circumstances; it need not attempt to correct all supposed abuses at once.

66 Cal. 2 d at 999 , 429 P.2d at 163, 59 Cal. Rptr. at 843, citing Silver v. Silver, 280 U.S. 117 (1929). 
Approaching the problem apart from preconceived categories, one would not tend to analyze the automobile guest statutes in terms of "classifications" at all. The method betrays a constitutional expediency: since our only available weapon is the equal protection clause, we shall look for "classifications." But once it is understood that the statutes' "purpose" is to give effect in this area to the doctrine of degrees of care, and to impose a higher duty of care on compensated than on gratuitous undertakings, then it becomes merely idle to argue that there is not "rational relationship" between their preeminent "classification" and their underlying "purpose." Putting the argument in these terms already tends to obscure the logical conception behind the notion of "rational relationship," which is a test to determine impermissible distinctions in the effect of legislation on different classes of people. A requirement that those who register to vote be at least six feet tall establishes a classification which would presumably be held to lack a rational relationship to any permissible purpose of the voting laws. Automobile guest statutes, by contrast, do not distinguish between classes of people but between courses of action: if someone does such and such, the legal consequences shall be so and so. A "classification" in this sense is effected by every piece of police legislation; but in the original sense of equal protection, this is no "classification" at all.

The law of equal protection has merely an incidental, strategic connection with the subject of automobile guest statutes. Brown $v$. Merlo represents an extreme example of judicial interventionism in the name of equal protection, and one from which the California Supreme Court has already retreated..$^{80} \mathrm{~A}$ more restrained judicial

so The reappraisal of Brown v. Merlo may also be observed in the California Supreme Court's treatment of the closely-related problem of the automobile "guest-driver" situation. The California guest statute had been amended in 1961 to provide that a car owner, injured while riding in his own car as the passenger of his "guest," should have the same restricted right of action against the driver as the guest passenger. Brown v. Merlo expressly declined to rule on the constitutionality of this part of the statute. 8 Cal. 3d at 862 n.3, 506 P.2d at 217 n.3, 106 Cal. Rptr. at 393 n.3. After Brown v. Merlo the legislature repealed the guestpassenger aspects of the statute but retained the guest driver aspects. WEST CAL. ANN. VEH. CODE $\S 17158$ (Supp. 1976). When the guest-driver provision was later considered in Schwalbe v. Jones, 14 Cal. 3d 1, 534 P.2d 73, 120 Cal. Rptr. 585 (1975), rev'd on rehearing, 16 Cal. 3d 514, 546 P.2d 1033, 128 Cal. Rptr. 321 (1976), the majority, in an opinion by Justice Tobriner (the author of the Brown v. Merlo decision) found, not surprisingly, that the guest-driver provision was also invalid. But while Brown v. Merlo had been unanimous, this decision was by a four-to-three vote over the strong dissent of Justice Sullivan. Schwalbe v. Jones was reversed on rehearing by a five-to-two vote, with Justice Sullivan writing the new majority opinion and Justice Tobriner the dissent. The opinions by Justice Sullivan in Schwalbe $v$. Jones comprise the most cogent published criticism of the equal protection excesses of Brown 
attitude toward the remaining guest statutes would still leave them a suitable object for the attention of legislatures and an interesting phenomenon in the law of torts. They cannot be evaluated in either context without an appreciation of their now-forgotten origin and rationale.

\section{CONCLUSION}

This comment has had a dual purpose. As a matter of general historical interest, it has traced the legal background of automobile guest statutes, indicating their foundations in the common law doctrine of degrees of care. This doctrine, originating in Roman law and first appearing in the common law in the law of bailments, offers one approach to a fundamental issue that must be confronted by any theory of civil obligations: the question of how far, and in what circumstances, the relations of the parties to a transaction may modify the duties of care owed by each party to the other. In modern tort law, with its tendency toward expanding civil liability, the doctrine of degrees of care has been severely eroded in such settings as the liability of charitable organizations. ${ }^{81}$ Although other policy considerations may be found to outweigh the considerations reflected in the doctrine of degrees of care in such situations, it is important that the notions of justice represented by the doctrine be at least recognized by the body that does the weighing.

The second, and related, object of this comment has been to demonstrate the inadequacy of analysis of those courts which have recently considered the constitutionality of automobile guest statutes under the equal protection clause. The motives of the courts whose decisions stretch equal protection doctrine to invalidate guest statutes are not difficult to discern. The view that the statutes have led to inefficient and undesirable results is widely held and easily supportable. ${ }^{82}$ A modern court might fairly conclude that Avery $v$.

v. Merlo. In his majority opinion in Schwalbe v. Jones on rehearing, Justice Sullivan cites the U.S. Supreme Court's decision in Silver $v$. Silver in a footnote explaining the California court's retreat from the broad language of Brown v. Merlo. 16 Cal. $3 \mathrm{~d}$ at $518 \mathrm{n} .2,546 \mathrm{P} .2 \mathrm{~d}$ at $1035 \mathrm{n} .2,128$ Cal. Rptr. at 323 n.2. In a later footnote, he quotes from Silver with approval. 16 Cal. 3d at 523 n.12, 546 P.2d at 1039 n.12, 128 Cal. Rptr. at 327 n.12.

sl See generally W. Prosser, LAW of TorTs § 133, at 992-94 (4th ed. 1974). Courts have also begun to do away with the distinctions among the degrees of care owed by owners and occupiers of land to trespassers, licensees, and invitees-requiring the same standard duty of care in all cases. See, e.g., Rowland v. Christian, 69 Cal. 2d 108, 70 Cal. Rptr. 97, 443 P.2d 561 (1968); W. Prosser, LAW of ToRTs $\$ 62$, at 398-99 (4th ed. 1974). These distinctions, however, are usually not enacted by statute and may therefore be discarded without the use of constitutional doctrine. See notes 76 supra \& 84 infra.

${ }^{22}$ For critical discussions of guest statutes, see, e.g., W. Prosser, LAW of TORTS 186-87 
Thompson ${ }^{83}$ is a preferable holding to Massaletti $v$. Fitzroy, or that common law principles, of whatever significance, must yield in time to modern policy considerations. ${ }^{84}$ It may be regrettable that the question of guest passenger liability was ever taken from the courts, where it might have undergone an evolution more readily responsive to contemporary needs. But once the legislature has intervened and the question has been settled by statute, further decisions as to the balance of policy objectives are no longer within a court's prerogative. To ignore this distinction, and to engage in collateral attack by means of a less than forthright use of the equal protection clause, is to seek to avoid the most fundamental restriction on the role of the judiciary in our jurisprudence.

Andrew Kull

(4th ed. 1971); Lascher, Hard Laws Make Bad Cases-Lots of Them (The California Guest Statute), 9 Santa Clara Law. 1 (1968); White, The Liability of an Automobile Driver to a Non-Paying Passenger, 20 VA. L. REv. 326 (1934); Note, The Present Status of Automobile Guest Statutes, 59 CoRNELl L. REv. 659 (1974); Comment, Judicial Nullification of Guest Statutes, 41 S. CAL. L. REv. 884 (1968); Comment, The Future of the Automobile Guest Statute, 45 TEMP. L.Q. 432 (1972).

*3 See text and note at note 54 supra.

*s Such was the rationale of McConville v. State Farm Mut. Auto. Ins. Co., 15 Wis. 2d 374,113 N.W.2d 14 (1962), reversing the judicial rule in Wisconsin limiting a driver's liability to his guest passenger. The court considered the legal principle by which liability may be limited where "certain relationships, founded on consent, exist between an actor and an injured party," but held that principle to be outweighed by "present-day customs and community attitude toward the use of automobiles." Id. at $377-78,113$ N.W.2d at 16. 